CRITICAI EDITIONS OF PRIMARY SOURCES

\author{
Laura Mesotten
}

European University Institute

\title{
A TASTE OF DIPLOMACY: FOOD GIFTS FOR THE MUSCOVITE EMBASSY IN VENICE (1582)*
}

\begin{abstract}
A vital factor governing early modern diplomatic relations was the practice of hospitality. To assure that the embassy began amicably, ambassadors had to be received with generosity. The nature and extent of diplomatic hospitality differed according to the host state, but it often included the offer of housing and victuals. This critical edition of a primary source aims to shed new light on the characteristics of diplomatic hospitality by carefully examining a list of expenses drafted by the Venetian office of the Rason Vecchie. This archival document provides a detailed account of all the food that was supplied to host a Muscovite delegation that visited Venice in 1582. In the first place, the article unravels the qualities and dynamics of Venetian food gifts by contextualising and comparing the source with additional Venetian records. Furthermore, it argues that the type of foodstuffs offered, the amount of money spent on them, and the splendour of festive banquets all communicated strong symbolic and political messages. By focusing the analysis on lists of expenses, the relevance of these documents for the study of diplomatic practices is illustrated. Overviews of financial transactions might seem static and dry accounts at first sight, however, when analysed closely, they reveal a great deal about the day-to-day operation of early modern diplomacy.
\end{abstract}

Keywords: Venice, hospitality, gift-giving, food gifts, diplomatic expenditure

* This article draws on a chapter of my PhD dissertation entitled 'Rituals of Diplomacy in the Venetian Republic', see: Laura Mesotten, 'Behind the Curtains of Diplomacy: The Household, Material Culture and Networks of French Ambassadors in Venice (1550-1610)' (unpublished doctoral thesis, European University Institute, 2017), pp. 25-80. I would like to thank Prof. Luca Molà for his generous assistance in deciphering the problematic words in the source. I am also very grateful to the two anonymous reviewers for their insightful comments and suggestions. 
When studying early modern diplomatic history, historians most often resort to the correspondence written by ambassadors, kings, and ministers as principal sources for the reconstruction of the functioning of diplomacy. Diplomatic dispatches contain a wealth of information and it is a common misconception that letters penned by ambassadors while on mission are formal accounts, simply depicting the state of public affairs. Even though the primary attention in diplomatic papers is devoted to political events, ambassadors reported on a wide variety of matters, ranging from high politics to private and domestic issues. Consequently, diplomatic correspondence allows historians to elucidate many facets of diplomacy, and society in general. Nevertheless, besides this extensive correspondence, numerous other sources related to early modern diplomacy have been preserved, such as lists of expenses, passports, and inventories of ambassadors' possessions. This vast and varied documentation provides an additional framework through which we can examine diplomatic environments.

This critical edition of a primary source, therefore, analyses a specific type of document that contributes greatly to our understanding of diplomatic practices: an overview of the expenses made by the Venetian Republic to host an embassy from Moscow in $1582 .{ }^{1}$ The record was composed by a certain Carlo Mazi, an official of the Ufficiali alle Rason Vecchie, the Venetian bureau that was assigned the task of entertaining foreign visitors. Mazi carefully noted down the daily expenditures incurred for the Muscovite delegation during the twenty-three days of their sojourn. Hence, the source reveals all the preparations that come with accommodating extraordinary ambassadors: repeatedly offering food, locating and furnishing an appropriate residence, arranging transportation and providing servants who assisted the diplomatic company. This article concentrates primarily on the first aspect of diplomatic hospitality, that is to say, gifts of food. The first section contextualises the source

1 Archivio di Stato di Venezia (ASV), Senato, Deliberazioni, Terra, filza (fz.) 85, [n. fol.] (25 September 1582). The analysis in this article starts from and is centred around the transcribed primary source. The information extracted from the source is subsequently contextualised by examining additional Venetian sources. Russian sources and literature are used to a certain extent, however, it is the main ambition of this article to uncover Venetian practices concerning diplomatic hospitality and food gifts. 
under examination by investigating hospitality practices and standard food gifts in the Venetian Republic. In the second part, the information that the list of expenses contains is carefully scrutinised and compared with similar sources in order to underline its importance for the field of diplomacy, and to fully comprehend how these types of documents should be approached and what we as historians can learn from them.

\section{VENETIAN HOSPITALITY: THE NATURE AND VARIETY OF REFRESCAMENTI}

When a new ambassador arrived in Venice, the Venetian government saw it as her duty to welcome the ambassador with great generosity. Their hospitality was not just motivated by the rules of courtesy, rather, it served a clear political agenda and the degree of hospitality was determined by the nature of the diplomatic mission and the status of the ambassador's sovereign. Moreover, hospitality was closely linked with gifts and the combination of the two was vital to the conduct of diplomatic ritual. ${ }^{2}$ Peculiar to the Venetian diplomatic protocol was that it was essentially the entire Republic, and not the doge (the ceremonial head of the state), who welcomed ambassadors and offered presents. ${ }^{3}$ Therefore, the Venetian senators had developed a carefully contrived

2 See: Felicity Heal, Hospitality in Early Modern England (Oxford: Clarendon Press, 1990); Maija Jansson, 'Measured Reciprocity: English Ambassadorial Gift Exchange in the Seventeenth and Eighteenth Centuries', Journal of Early Modern History, 9, no. 3 (2005), 348-70 (p. 354). Some examples of recent studies on the diplomatic gift in various European contexts include: Diana Carrio-Invernizzi, 'Gift and Diplomacy in Seventeenth-Century Spanish Italy', The Historical Journal, 51, no. 4 (2008), 881-99; Russell E. Martin, 'Gifts for the Bride: Dowries, Diplomacy, and Marriage Politics in Muscovy', The Journal of Medieval and Early Modern Studies, 38, no. 1 (2008), 119-46; Catherine Fletcher, "Those Who Give Are Not All Generous': Tips and Bribes at the Sixteenth-Century Papal Court', EUI Working Papers MWP 2011/15, European University Institute, 2011, 1-10; L'Arte del Dono: Scambi Artistici e Diplomazia tra Italia e Spagna, 1550-1650, ed. by Marieke von Bernstorff and Susanne Kubersky-Piredda (Milan: Silvana Editoriale, 2013). For a good overview of gift exchange in the Islamic world, see: Gifts of the Sultan: The Arts of Giving at the Islamic Courts, ed. by Linda Komaroff (New Haven: Yale University Press, 2011).

3 Edward Muir, Civic Ritual in Renaissance Venice (Princeton: Princeton University Press, 1981), pp. 254-56. 
ceremonial strategy where gestures and gifts functioned as a form of diplomatic investment; the gifts had to represent the power and wealth of the Venetian state as a whole, and at the same time promote the export of artisanal and industrial products. A customary component of the Republic's hospitality was the gift of refrescamenti or refreshments, a package filled with various foodstuffs and beverages. These food provisions were of crucial importance to Venetian hospitality strategies and can be considered as the first diplomatic gifts that ambassadors received. ${ }^{4}$

Food is one of the oldest instruments of diplomacy. In the realm of diplomatic hospitality and gift-giving, food has been constantly used as a tool to show esteem and affection, and to facilitate political and social bonding. State visits of foreign delegates prompted the host state to present numerous foodstuffs as a sign of willingness to stimulate and maintain cordial relationships. Moreover, splendid banquets were traditionally organised for eminent visitors, where culinary creations and elaborate spectacles had to astound the guests. These dinners were meticulously prepared: the setting of the table, the duration of the feast, and the foodstuffs offered all communicated a calculated message. The meal also served as an instrument for informal political mediation and as an economic device to promote national products. ${ }^{5}$ Despite the omnipresence of food in daily diplomatic interactions, the historiography of diplomatic gifts, and of diplomacy more generally, has often failed to analyse the importance of food gifts. ${ }^{6}$ Nonetheless, a closer look at the type of food gifts that circulated in the Venetian Republic reveals a great deal about the symbolic value and meaning of

${ }^{4}$ Other traditional Venetian diplomatic gifts include: gold chains, textiles, and various luxury objects, such as silverware and glass.

${ }^{5}$ On banquets in the Renaissance, see, especially: Michel Jeanneret, $A$ Feast of Words: Banquets and Table Talk in the Renaissance, trans. by Jeremy Whiteley and Emma Hughes (Cambridge: Polity Press, 1991). For an overview of banquets in Venice, see: Lina Urban, Banchetti Veneziani dal Rinascimento al 1797 (Belluno: Strategy \& People, 2007).

6 Studies that do analyse the gift of food and its meanings include: Felicity Heal, 'Food Gifts, the Household and the Politics of Exchange in Early Modern England', Past \& Present, 199, no. 1 (2008), 41-70; Sara Bercusson, 'Gift-Giving, Consumption and the Female Court in Sixteenth-Century Italy' (unpublished doctoral thesis, University of London, 2009). 
foodstuffs, which in turn enriches our understanding of the performance of early modern diplomacy.

Eric Dursteler, who has worked extensively on Venetian-Ottoman relations, has already underlined the central role played by food in the political strategies of Venetian ambassadors abroad. They employed food to uphold the reputation of the Republic, to curry favour with local elites, and to gather intelligence. These practices have been collectively labelled as 'culinary diplomacy', which produced many political successes for Venice. ${ }^{7}$ Additionally, the Venetian Republic understood how food could be applied to establish friendly relationships with foreign ambassadors who frequented the city itself. This belief is strongly reflected in the transcribed source listing the refrescamenti offered to the Muscovite embassy in 1582. However, before emphasising these specific food gifts, the general characteristics of sixteenth-century Venetian food packages will be outlined through an analysis of similar lists of expenses, with the aim of uncovering trends and broadening our knowledge of diplomatic hospitality.

Every ambassador, regardless of his rank or the purpose of his mission, was offered refrescamenti immediately upon arrival. The officials of the Rason Vecchie were responsible for locating and purchasing these foodstuffs. Their accounts illustrate the development of a certain shopping pattern, since they repeatedly frequented the same shops and street venders to procure the desired commodities. By building this network with shopkeepers, they were able to quickly obtain quality goods. The type of products offered rarely varied. Firstly, fine sugar was given to practically every foreign representative residing in Venice. Secondly, various types of nuts were a typical Venetian offering: pistachios, almonds, pine nuts, and walnuts. A third constant feature of the refrescamenti were herbs and spices, such as cinnamon and pepper in its various forms (rough, ground, and crushed); coriander; and cloves. Fourthly, fresh

7 Eric R. Dursteler, 'Food and Politics', in A Cultural History of Food, ed. by Fabio Parasecoli and Peter Scholliers (London: Berg, 2012), III: A Cultural History of Food in the Renaissance, ed. by Ken Albala (2012), pp. 83-100; Eric R. Dursteler, "A Continual Tavern in My House': Food and Diplomacy in Early Modern Constantinople', in Renaissance Studies in Honor of Joseph Connors, ed. by Machtelt Israëls and Louis A. Waldman (Cambridge: Harvard University Press, 2013), pp. 166-71. 
fruits were often added to the gift package: pears, pumpkins, peaches, apples, cherry plums, jujubes, lemons, limes, and citrons. And lastly, in some cases, a variety of fish or meat was offered. A barrel of Moscato wine always accompanied this food. All these components were arranged into small packages, since a respectable presentation was essential for any gift. For example, the spices and nuts were always presented in scatole, piteri, vasetti - general terms for jars and boxes - or in an albarello, a maiolica earthenware jar used by apothecaries to store their medicines and delicacies. ${ }^{8}$

Besides these unprocessed products, the Venetian government also gifted various zucchari (sugar confections) to their diplomatic guests. Due to the fairly high price of sugar and the labour-intensive preparation of sweets, sugar confections were expensive. Therefore, during dinner parties and official feasts, sweets were prominently served as a separate course so as to underline their social function: the exhibition of the host's status and splendour. Moreover, a medicinal benefit was attributed to sugar: it was believed that, amongst other things, it strengthened the heart, offered protection for rheumatism, and was beneficial to the stomach and digestion. ${ }^{9}$ It is thus not surprising that Venice used sugar candies as gifts to ambassadors, as they reflected the Republic's magnificence and wealth, and at the same time showcased a more private concern for the ambassador's health.

Venetians were masters in refining sugar and making all kinds of delicacies. Confetti or comfits, sugar-coated confectionery made with nuts, spices, and fruits, are a typical example of these Venetian sweets. ${ }^{10}$ Also in other Italian city-states, confetti were a standard component of the menus served at banquets, and they were used as gifts during various rituals and ceremonies. ${ }^{11}$ The same was true for conditi, which

8 ASV, Ufficiali alle Rason Vecchie, busta (b.) 378, passim; ibid., b. 379, passim.

9 Maria Pia Pedani, In Nome del Gran Signore: Inviati Ottomani a Venezia dalla Caduta di Costantinopoli alla Guerra di Candia (Venice: Deputazione Editrice, 1994), p. 93; James Shaw and Evelyn Welch, Making and Marketing Medicine in Renaissance Florence (Amsterdam: Rodopi, 2011), pp. 200-09.

${ }^{10}$ For more information on the making of confetti, see: Shaw and Welch, p. 200.

11 Elizabeth S. Cohen, 'Miscarriages of Apothecary Injustice: Un-Separate Spaces of Work and Family in Early Modern Rome', in Spaces, Objects and Identities in 
are candied fruits, nuts, and condiments. In the lists of refreshments that were presented to arriving ambassadors, we see that both confetti (of pistachio, almond, cinnamon, and coriander) and conditi (of diverse fruits and almonds) were a standard diplomatic gift. Additionally, other sweets were a typical feature of the refrescamenti: pinochiati, cakes from pine nuts and sugar; pastries and biscuits made with pistachio nuts; and cotognato, or quince jelly. ${ }^{12}$

As these examples of costly sugared goods suggest, the foodstuffs offered to ambassadors were mostly products with a prestigious and ceremonial connotation. This can be further deduced from the other typical food gifts outlined above. Firstly, the Levantine spices, such as cinnamon and cloves, were considered spices for the rich. Secondly, amongst the meats presented to foreign envoys, we can distinguish partridge, duck, hare, pheasant, and turkey, all expensive game and standard features on fashionable noble tables. ${ }^{13}$ Thirdly, pistachios and almonds were relatively expensive nuts, which were accordingly considered as delicacies. ${ }^{14}$ Still more than economic worth, the conveying of strong symbolic messages about prestige and prowess gave these gifts their value, as they embodied and validated the prosperity of the Republic.

\section{THE RECEPTION OF THE MUSCOVITE EMBASSY IN 1582}

In some cases, the range of hospitality extended beyond the proffering of the customary refreshments. The Republic sent entire meals, every morning and evening, to certain extraordinary ambassadors, or hosted festive public meals. ${ }^{15}$ A detailed account of both daily food gifts and the celebration of a banquet is given in the overview of the expenses incurred for the visit of a Muscovite embassy, accompanied by the

Early Modern Italian Medicine, ed. by Sandra Cavallo and David Gentilcore (Oxford: Blackwell Publishing, 2008), pp. 8-32 (p. 5).

12 ASV, Ufficiali alle Rason Vecchie, b. 378, passim; ibid., b. 379, passim.

13 Joanne Marie Ferraro, Venice: History of the Floating City (New York: Cambridge University Press, 2012), pp. 44-45; Ken Albala, Food in Early Modern Europe (Westport: Greenwood Press, 2003), pp. 68-69.

14 Albala, pp. 55-57.

15 Since extraordinary ambassadors came to celebrate special occasions or negotiate important treaties, they were treated very generously. 
Jesuit Antonio Possevino, which stayed in Venice on its way to Rome in August 1582. Possevino had been sent to Muscovy in 1581 as the papal emissary of Pope Gregory XIII to negotiate a truce between Ivan the Terrible, tsar of Muscovy, and Stefan Batory, king of Poland. Papal mediation came after the tsar's formal request for help in 1581. The pope hoped that his intervention would lead to the establishment of regular diplomatic relations between Rome and Muscovy, the latter's adherence to the Christian league against the Turks, and the union of the Muscovite Church with Rome. None of these goals materialised, but Possevino did arrange the peace treaty of Jam Zapolski, which was signed on 15 January 1582. In March 1582, Possevino departed from Moscow and escorted the tsar's representative, Iakov Molvianinov, to Rome. As events proved, this ambassador would accomplish nothing in Rome, which was in fact the tsar's, as he no longer had a need for the pope after the signing of the truce. ${ }^{16}$

On their way to Rome, Antonio Possevino and the Muscovite ambassador halted in various cities, including Venice. Yet Possevino only mentioned briefly their stay in the Venetian Republic in the account of his journey. ${ }^{17}$ Sources in the Archivio di Statio di Venezia provide us with additional information about the embassy. The diplomatic party consisted of thirty people: first of all, Muscovite Ambassador Iakov Molvianinov and his entourage: one secretary, one translator, and four servants; secondly, Possevino and his suite: two of his nephews (who were Jesuit priests), one secular secretary, one young Polish boy, Giovanni Battista Pallavicini from the famous Pallavicini family of Milan, and five schiavi, spagnoli, and marchiani; ${ }^{18}$ thirdly, there were some additional

16 Antonio Possevino, The Moscovia of Antonio Possevino, S.J., ed. and trans. by Hugh F. Graham (Pittsburgh: University of Pittsburgh, 1977); Stéphane Mund, 'La Mission Diplomatique du Père Antonio Possevino (S.J.) chez Ivan le Terrible en 1581-1582 et les Premiers Écrits Jésuites sur la Russie Moscovite à la Fin du XVI ${ }^{e}$ Siècle', Cahiers du Monde Russe, 45, no. 3-4 (2004), 407-40.

17 Possevino, pp. ix, xxiv, 22-23.

18 The Italian word schiavi can refer both to slaves and the Slavs, people belonging to the Slavic ethno-linguistic group. It would be peculiar if Possevino had Spanish slaves, so all these terms most likely refer to the nationalities of these five individuals: Slavs, Spaniards, and Marchiani, inhabitants from the Marches (a region in central Italy). The Slavs are identified by Stéphane Mund; he states that Possevino was accompanied 
members in the entourage: friars who served in the house and attended to the ill, a Scottish gentleman, and more people in Possevino's train. Furthermore, the Venetian government put servants at the embassy's disposal, including four gondoliers, two despensieri (who were responsible for the food and kitchen), one porter, and four chefs and sous-chefs. ${ }^{19}$

On either the first or second day of August 1582 the Muscovite delegation arrived at the island of San Giorgio in Alga, where they were subsequently housed for one night. ${ }^{20}$ It was the custom in Venice to welcome new ambassadors at a well-selected small island in the lagoon. This ceremonial decision was imbued with a political meaning, that is, the island of reception was linked with the ambassador's status. In order to understand this connection, one must consider the distance of the island from St. Mark's Square, the centre of power. In doing so, one should apply the same logic that was valid during diplomatic encounters between sovereigns: when greeting each other, neither prince wished to cover a greater distance than the other, therefore, the place of the encounter was carefully measured. However, when there was a clear divergence in status between princes, the one with the inferior rank had to cover the greater distance. ${ }^{21}$

In sixteenth-century Venice, a consideration of these spatial strategies translated into the practice whereby Venetian officials honoured ambassadors representing high-level monarchs by showing their willingness

by the Jesuit brothers Giovanni Paolo Campana, Stefan Drenocky, Andrei Modestyn, and Michele Morieno. The choice of these specific Jesuit brothers was well-considered, since the first three were all familiar with the Slavic world. Drenocky and Modestyn because of their ancestry, respectively Croatian and Czech, and Campana had lived for eleven years in Bohemia and Moravia, which had made him familiar with the Slavic world and the Czech language. See: Mund, 407-40 (p. 411).

19 ASV, Senato, Deliberazioni, Terra, fz. 85, [n. fol.] (25 September 1582).

${ }^{20}$ Two dates can be found in the archival records. The account left by the Collegio states that the diplomatic party arrived on the first of August; this date has been accepted by Dubrovskiy in his article on the Muscovite embassy. However, the financial record composed by the Senato and Molvianinov's travel account give the second of August as arrival date.

${ }_{21}$ Monique Chatenet, 'The King's Space: The Etiquette of Interviews at the French Court in the Sixteenth Century', in The Politics of Space: European Courts, ca. 1500-1750, ed. by Marcello Fantoni, George Gorse and Malcolm Smuts (Rome: Bulzoni, 2009), pp. 193-208 (p. 195). 
to advance a longer distance to greet them. Consequently, the island on which most of the diplomatic representatives of the larger powers were greeted, the island of Santo Spirito, was more remote from the main island of Venice than the island of Santa Maria della Grazia, where ambassadors of less powerful rulers were welcomed. ${ }^{22}$ According to the Venetian ceremonial records, the island of San Giorgio in Alga was not regularly used for diplomatic welcome receptions during the sixteenth century. ${ }^{23}$ Still, its remoteness from St. Mark's Square was appropriate to the honour and respect that the Muscovite envoys deserved. Clearly the Venetian ceremonial space was indissolubly connected with the water that surrounded the city. The sea, the lagoon and its islands not only constituted a majestic backdrop for the reception of foreign dignitaries, they also endowed the Venetian officials with the advantage of control over the ambassadors' movements. They could therefore manipulate space to qualify rank and hierarchy. ${ }^{24}$

In addition to location, another barometer of rank during the diplomatic entry was the composition of the cohort of Venetian officers who came to greet the ambassador. They travelled to the island where the ambassador was staying to formally welcome him and guide him to his residence in the city. Typically, the party was composed of thirty pregadi, members of the Venetian Senate, which was also the number of Venetian officials that greeted the Muscovite embassy. The pregadi were dressed in silk robes in order to display the main product of

22 The island selected for an ambassador's welcome was thus linked with his nationality: delegates of the Holy Roman Empire were accommodated at the island of San Secondo; French, Spanish, English and Papal ambassadors stayed at the island of Santo Spirito; and for the ambassadors from smaller principalities, such as Savoy, Tuscany, Mantua, Ferrara, Parma and Urbino, the island of Santa Maria della Grazia was selected. ASV, Collegio, Cerimoniali, registro (reg.) 1, passim; ibid., reg. 3, passim.

23 The island of San Giorgio in Alga seems to have been used more frequently starting from the seventeenth century. Both French Ambassador Philippe de la Canaye and the extraordinary delegate of the States General of the Low Countries, Cornelis van der Mijle, were housed here during their first nights in Venice. ASV, Collegio, Cerimoniali, reg. 3, fol. $4^{\mathrm{r}}$ (18 October 1601); ibid., fol. $29^{\mathrm{r}}$ (8 November 1609).

${ }^{24}$ On this subject, see, also: Stefanie Cossalter, 'Dai Porti alle Isole: Cerimoniali di Accoglienza nella Serenissima', in Spazi Veneziani: Topografie Culturali di una Città, ed. by Sabine Meine (Rome, Venice: Viella, 2014), pp. 125-48. 
Venice's textile industry and the principal source of the city's wealth. Etiquette demanded that on the day of the public audience with the doge, the Muscovite ambassador was escorted to the Doge's Palace by the same group of senators. This first audience featured the presenting of credentials and letters, exchanging the customary words of kindness and respect, expressing hopes for an enduring friendship between the two states, and the offering of a gift of sable furs to the doge. The report of the audience reveals that the stopover in Venice was also intended to discuss commercial agreements. ${ }^{25}$

The analysis of space and actors has established that the Venetian state consciously calculated every gesture. The authorities staged a spectacle by creating a proper setting and regulating the conduct and experience of the participants. The ceremony was thus for the most part a performance, controlled by appearances and pageantry. In the same way, the food gifts offered to the Muscovite embassy were selected with care. For the duration of their sojourn, which lasted twenty-three days, the Venetian Republic provided the entire company with daily food provisions. They succeeded in their goal of publicising Venetian strength and prosperity through foodstuffs, as the Muscovites were impressed by the food they received and praised its abundance and the fact that their dishes were prepared by the doge's own cook. ${ }^{26}$ They were particularly keen on melons, of which they ate five hundred (according to Possevino). This overindulgence upset the stomachs of two men of the diplomatic entourage. ${ }^{27}$

${ }^{25}$ A description of the entry and public audience of the Muscovite delegation can be found in: ASV, Collegio, Cerimoniali, reg. 1, fols 93v $-94^{\mathrm{r}}$; ASV, Collegio, Esposizioni Principi, reg. 5, fols 102 $-03^{\mathrm{r}}$; Pamjatniki Diplomatičeskich Snoshenii Drevnej Rossii s Derzhavami Inostrannymi, 10 vols (1851-1871), I (St. Peterburg: Izdatel'stvo: Tip. II Otdeleniya Sobstvennoy Ye.I.V. Kantselyarii, 1851), pp. 875-77. According to the Russian account, only eleven, and not thirty, pregadi welcomed the diplomatic delegation: Pamjatniki diplomatičskich, pp. 875-76. I would like to thank the translator for proving me with an English translation of this source edition.

26 Pamjatniki diplomatičeskich, p. 875.

27 I. V. Dubrovskiy, 'Novyye Dokumenty po Istorii Otnosheniy Rossii i Italii pri Ivane Groznom', in Russkiy Sbornik: Issledovaniya po Istorii Rossii, ed. by M. Jovanovic and others, 14 vols (Moscow: Regnum, 2004-2013), XIV (2013), pp. 7-72 (p. 63). I would like to thank the translator for proving me with an English translation of this article. 
Table 1: Daily food gifts offered to the Muscovite embassy (1582) ${ }^{28}$

\begin{tabular}{|c|c|}
\hline $\begin{array}{l}\text { Basic } \\
\text { Necessities }\end{array}$ & $\begin{array}{l}\text { Vinegar (asedo, it. aceto); oil (olio); bread (pani); rice (risi); black and white } \\
\text { salt (sal negro e bianco, it. sale nero e bianco) }\end{array}$ \\
\hline $\begin{array}{l}\text { Dairy } \\
\text { Products }\end{array}$ & $\begin{array}{l}\text { Mozzarella (cai de late, it. for di latte, mozzarella); marzolino, cheese made } \\
\text { from the spring season's first milk; zonchiada or giuncata, a light, fresh } \\
\text { cheese; formazo piacentin (it. formaggio piacentino), cheese from the region } \\
\text { of Piacenza; butter (onto sotil, it. burro) }{ }^{29}\end{array}$ \\
\hline Fish & $\begin{array}{l}\text { Sea bass (brancini, it. branzini); young sea bass (varuoli, it. branzini, sp- } \\
\text { igole); sturgeon (porcelle, it. storioni); croaker (corbi, it. ombrine); mullet } \\
\text { (cievali, it. cefali); gilthead bream (orae, it. orate); surmullet (barboni, it. } \\
\text { triglie); sole (sfogi, it. sogliole) }\end{array}$ \\
\hline Meat & $\begin{array}{l}\text { Capon (caponi, it. capponi); blackcap (caponere, it. capinere); pigeon (colom- } \\
\text { bini, it. piccioni, colombi); polastri, young poultry such as pigeon; polanche, } \\
\text { a type of poultry; duck (anere, it. anatre); turkey (gali di india, it. tacchini); } \\
\text { veal (vedelli, it. vitelli); beef (manzo); loins (nomboli, it. lombi); tongues } \\
\text { (lengue); salami (salumi); mortadelle, a type of Italian sausage; lard (lardo) }\end{array}$ \\
\hline $\begin{array}{l}\text { Fruit and } \\
\text { Vegetables }\end{array}$ & $\begin{array}{l}\text { Oranges (narance, it. arancie); citrons (cedri); plums (susini, it. prugne); } \\
\text { melons (meloni); watermelons (angurie); figs (fighe, it. fichi); peaches } \\
\text { (perseghe, it. pesche); grapes (uva); herbs, greenery (erbazi); salad (salad, it. } \\
\text { insalata) }\end{array}$ \\
\hline Spices & Coriander (tamaro, it. coriandolo); spitiarie, various spices \\
\hline Sweets & Confections (confetioni) \\
\hline Wine & $\begin{array}{l}\text { White wine (vin bianco, it. vino bianco); malvasia, malmsey wine; romania, } \\
\text { sweet Greek wine; liatico (it. aleatico), sweet Tuscan wine }\end{array}$ \\
\hline Medicines & $\begin{array}{l}\text { Cassia, a medicinal plant; syrups (siropi, it. sciroppi); distilled water (agua } \\
\text { stilada, it. acqua distillata); distilled spirits, healing water (agua de vitta, it. } \\
\text { acqua di vita) }\end{array}$ \\
\hline
\end{tabular}

28 The English translation is always given first with the original Venetian word, as it is written in the consulted source, between brackets, accompanied by the corresponding modern Italian version (it.). When the Venetian and Italian words are the same, only one single term will be listed between brackets. If no English translation is available, the Venetian original, and the Italian equivalent (where applicable), are provided, followed by a definition of the word. The consulted dictionary for the Venetian dialect is: Giuseppe Boerio, Dizionario del Dialetto Veneziano, $3^{\text {rd }}$ edn (Venice: Reale Tipografia di Giovanni Cecchini Editore, 1867).

29 Onto sotil can refer to butter, cheese, cream, and also pig's fat or lard. I have opted for the most general translation: butter. 
In addition to these daily refreshments, a banquet was prepared to honour the Muscovite delegation. Entertaining ambassadors with dinner parties was an essential feature of diplomatic ceremonial in Venice. This tradition dated back at least to the beginning of the sixteenth century, when sumptuous dinners were already being organised for ambassadors. ${ }^{30}$ The examples from the second half of the sixteenth century and the early seventeenth century demonstrate the continuation of these festive repasts, and underline their ubiquity. These meals were prepared for a variety of ambassadors: French, Spanish, Polish, Dutch, Scottish, Swiss, Parmese, Navarrese, and Ottoman diplomatic agents were all invited to splendid feasts. ${ }^{31}$ In the majority of the instances found, the meal was hosted in the Arsenal, the enormous warehouse where arms were stored and ships were built and repaired. It was thereby the most prominent symbol of Venice's maritime and military authority. ${ }^{32}$ Likewise, the banquet celebrating the Muscovite visitors was hosted in the Arsenal. This location was undoubtedly deliberately chosen, as it was a way for Venice to perpetuate and propagate an image of itself as a pillar of naval strength in the Mediterranean, boast of its industrial and military power, and ensure respect and esteem from foreigners. Therefore, this is a very fitting illustration of how lavish banquets were employed to affirm the status of the host nation.

30 Marin Sanudo, Diarii di Marino Sanuto, ed. by Rinaldo Fulin and others, 58 vols (Venice: Visentini, 1879-1903), XVII (1886), col. 543.

31 ASV, Collegio, Cerimoniali, reg. 1, fol. $71^{\mathrm{v}}$ (6 September 1578); ibid., fol. $73^{\mathrm{r}}$ (25 November 1578); ibid., fol. 91 ${ }^{\mathrm{r}}$ (14 October 1581); ibid., fol. 103 ${ }^{\mathrm{r}}$ (1 April 1585); ibid., fol. $117^{v}$ (5 December 1589); ibid., fol. 129v (12 December 1594);

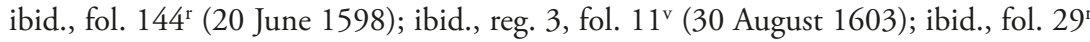
(8 November 1609); ibid., fol. 34 (31 July 1611); ibid., fol. $35^{\mathrm{r}}$ (23 January 1612); ASV, Senato, Deliberazioni, Terra, reg. 57, fol. 18 ${ }^{\mathrm{r}}$ (21 October 1586).

32 This was the case for the Ottoman, Navarrese, French, Scottish, and Dutch (extra)ordinary ambassadors: ASV, Collegio, Cerimoniali, reg. 1, fol. $91^{\mathrm{r}}$ (14 October

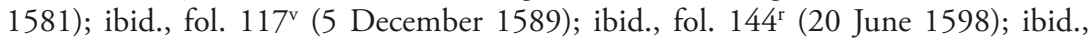
reg. 3, fol. $11^{\mathrm{v}}$ (30 August 1603); ibid., fol. $29^{\mathrm{r}}$ (8 November 1609); ibid., fol. $34^{\mathrm{r}}$ (31 July 1611); ibid., fol. $35^{\mathrm{r}}$ (23 January 1612); ASV, Senato, Deliberazioni, Terra, reg. 57, fol. $18^{\mathrm{r}}$ (21 October 1586). This varied national group of ambassadors suggests that probably also for many other ambassadors the dinners were hosted in the Arsenal. 
On the day of the feast, a four-course meal was prepared for the Muscovite representatives, for which the officers of the Rason Vecchie bought the basic ingredients, such as vinegar, oil, sugar, no fewer than 140 breads, and white and malmsey wine. The dishes were composed of mainly fish and fruit, in great numbers and varieties. The Venetian officials opted for fish as a way to please Molvianinov and his entourage and to show respect for their traditions. Fish was a main component of the Muscovite diet due to a steady supply of freshwater species, as well as Orthodox fasting laws. While it was permissible to eat fish, these laws forbade the consumption of meat during fasting periods, which altogether lasted for roughly half the year. The Muscovite diplomats' visit to Venice coincided with the traditional two-week fast before the Feast of the Dormition on the $15^{\text {th }}$ of August. ${ }^{33}$ As a result, Venetian cooks prepared an elaborate fish menu that consisted of typical varieties found in the Venetian lagoon and the northern Adriatic Sea: sea bass (brancini, it. branzini); young sea bass (varuoli, it. branzini, spigole); sturgeon (porcelle, it. storioni); croaker (corbi, it. ombrine); mullet (cievali, it. cefali); gilthead bream (orae, it. orate); surmullet (barboni, it. triglie); sole (sfogi, it. sogliole); caviar (caviaro, it. caviale); fish eggs (bottarghe); anchovy (inchio, it. sardoni, acciuge); gills of the Mediterranean moray (baise di morena); and tarantello, the stomach of tuna. ${ }^{34}$ Fruits were also present in abundance: oranges (narance, it. arancie); citrons (cedri); melons (meloni); watermelons (angurie); figs (fighe, it. fichi); peaches (perseghe, it. pesche); three types of grapes (uva); raisins (uvapasa, it. uva

33 Geoffrey A. Hosking, Russia and the Russians: A History (Cambridge: The Belknap Press of Harvard University Press, 2001), p. 11; Antonia-Leda Matalas, Eleni Tourlouki and Chrystalleni Lazarou, 'Fasting and Food Habits in the Eastern Orthodox Church', in Food and Faith in Christian Culture, ed. by Ken Albala and Trudy Eden (New York: Columbia University Press, 2011), pp. 189-204.

${ }^{34}$ Fish were plentiful in Venice and an important component of the Venetian diet. Francesco Sansovino recounted in his Venetia Città Nobilissima that at the fish markets of St. Mark and the Rialto you could find twice a day, all year round, a wide variety of fish: Francesco Sansovino, Venetia Città Nobilissima et Singolare, con Aggiunta da D. Giustiniano Martinioni (Venice: Stefano Curti, 1663), p. 316. The translation of the Venetian terms for the various types of fish is based on: Marcello Brusegan, 'Cisame de Pesse Quale Tu Voy': Il Pesce nelle Tavole Veneziane nei Secoli XIV-XVI (Venice: Centro Internazionale della Grafica di Venezia, 1992), pp. 86-88. 
passa); and more unspecified fruit. Lastly, cakes, pastries, typical Venetian sugar confections, and various spices were displayed and served during the banquet. Additionally, the Rason Vecchie supplied suitable furnishings, hired cooks and a scalco (the chief steward who oversaw the kitchen staff, food, and finances, and managed every detail of dinner parties), and arranged a musical performance by fourteen singers and musicians. ${ }^{35}$

Although these luxurious banquets were not uncommon in Venice, the especially grand reception of the Muscovite embassy might have been a way of reciprocating the Muscovite diplomatic custom of providing foreign ambassadors with large amounts of food. Immediately upon their arrival in Muscovite territory, diplomatic delegates were also offered a great quantity of food and beverages, and these food gifts were continuously repeated throughout the ambassadors' sojourn in Muscovy. Thus, the Venetian Senate's honourable treatment of Molvianinov may have been intended to equal, or even outshine, the tsar's treatment of European envoys in Moscow.

Similarly, upon his arrival in Rome, Molvianinov was welcomed with considerable pomp. The Vatican modelled Molvianinov's reception on how Possevino was greeted in Muscovy, and they imitated Russian diplomatic customs with regard to the daily allocation of victuals. Hence, the pope ordered that enormous quantities of food were to be provided. The amount of meat alone was impressive: four turkeys, fifty quails, fifty warblers, two dozen doves, half a dozen capons, fifty pigeons, two hundred pounds of veal, and so forth. ${ }^{36}$ All of these dishes were prepared by the pope's cooks. ${ }^{37}$ The people of Rome viewed the eating habits of the Muscovites with both amazement and disgust: '[...] these Barbarian people have become famous in Rome for their epicurean lifestyle [...];'38 and the fact that the Muscovites became ill in

35 ASV, Senato, Deliberazioni, Terra, fz. 85, [n. fol.] (25 September 1582).

36 By the time that Molvianinov arrived in Rome, the fasting period had ended so it was again permissible to consume meat.

37 Dubrovskiy, pp. 7-72 (p. 59).

${ }^{38}$ Letter from Francesco Dzerini to Antonio Serguidi, 5 October 1582: Archivio di Stato di Firenze (ASF), Mediceo del Principato, Carteggio dei Segretari, fz. 1187, [n. fol.]: '[...] questa gente barbara lassa in Roma fama di vita epicurea [...]'. Quoted in: Dubrovskiy, pp. 7-72 (p. 62). 
Rome was generally attributed to their gluttony. ${ }^{39}$ The Italians were also horrified by the fact that the diplomatic party added vodka to expensive wines. However, this can be explained by the fact that in Muscovy, wine was only served at the tsar's table, consequently, the ambassador and his entourage were not familiar with the Italian custom of constantly drinking it. ${ }^{40}$

In total, the sojourn of the Muscovite delegation had cost the Venetian Republic 589 ducats, 2 lire, and 13 soldi, of which the bulk was spent on food provisions. ${ }^{41}$ Besides the Republic's desire to match Muscovite food rituals, the large sum also reflected the Venetians' esteem for the tsar, as well as the latter's international status. Other similar documents reveal that the quantity and costs of food gifts were indeed associated with the degree of honour and respect that was rendered to the ambassador's sovereign. As a result, the comparison of various sources can expose hierarchical differentiations between nations. The table below outlines the amounts spent on refreshments for foreign representatives during the 1570s, which was around the same period that the Muscovite embassy frequented the city. ${ }^{42}$ It shows that ambassadors

39 They supposedly ate seven times a day, which made them ill, see: Letter from Francesco Babbi to the Medici court, 17 September 1582: ASF, Mediceo del Principato, Relazioni con Stati Italiani ed Esteri, Roma, fz. 3603, fols 427 $-27^{\mathrm{v}}$ : 'Il papa gli vuole spedir presto, poiché magnan' tanto, che tutti cascan' malati, mangiando 7 volte il giorno.' (The pope wants to send them away soon, since they eat a lot, they all fell ill, eating seven times a day). Quoted in: Dubrovskiy, pp. 7-72 (pp. 62-63).

${ }^{40}$ Ibid.

${ }^{41}$ Hospitality was not the only gift awarded to the Muscovite delegation. As was the custom in Venice, Molvianinov received a gold chain as a leave-taking present when he departed from the city. Besides the ambassador, the Muscovite secretaries also were offered a gold chain, although with a lower value than that of Molvianinov. According to Possevino's account, the Muscovites were not satisfied with these gifts and demanded silks and other treasures. The interpreter, however, did not communicate their request. Possevino, p. 23; Pamjatniki diplomatičeskich, p. 878. On gold chains as a traditional diplomatic gift in Venice, see: Mesotten, pp. 58-60.

42 This table was composed using the accounts of the Ufficiali alle Rason Vecchie (b. 378 and 379). I could only trace detailed lists with specific food gifts and their costs for the 1570s. The reason for the high number of ambassadors visiting Venice in 1577 was the appointment of Doge Sebastiano Venier, who the ambassadors came to congratulate. 
from smaller courts and republics, such as Ferrara, Florence, Parma, Mantua, Milan, Urbino, Genoa, Savoy, and the Swiss canton of Grisons, always received a gift basket with a value of between twenty-three and twenty-nine ducats. ${ }^{43}$ For ambassadors representing states that exerted more power on the international scene, such as the Papal States and France, the Republic assigned a higher sum of money. With regard to a legate from Rome, a detailed list of refrescamenti with a value of thirty-one ducats is preserved in the archives. ${ }^{44}$ While for France no specific information could be retrieved for the 1570 s, similar examples for later periods can be given: in 1586, a sum of 150 ducats was allotted and in 1596, the refreshments were valued at 500 ducats. ${ }^{45}$ Two other states that stand out in the table below are Poland and Navarre for the year 1573, when ambassadors of both kings visited Venice. The fact that the standard amount was doubled with regard to the Polish embassy can be explained by the fact that the brother of the French King Charles IX, Henry duke of Anjou, had been crowned as Polish king. The ambassadors representing the king of Navarre, Henry III of Bourbon, later King Henry IV of France, received food gifts with an even higher value, namely one hundred ducats. Even though Navarre was a small kingdom, Henry of Bourbon was an important king and a prominent figure in international politics as the leader of the French Huguenot party. His status is probably the reason why Venice honoured his ambassador with a more expensive and lavish package of foodstuffs. This outline clearly shows that the hierarchical differentiation imposed on states, with sovereigns placed lower or higher on the international political ladder, was mirrored in the value of the diplomatic food gifts. Therefore, analysing food gifts offers historians an additional, perhaps more original, way to investigate political hierarchies and to measure the importance of status, power, and esteem.

43 The average amount spent on one package of food gifts during the second half of the sixteenth century was twenty-five ducats. This estimate is based on the records left by the Ufficiali alle Rason Vecchie (b. 378 and 379), the Collegio, Cerimoniali (reg. 1 and 3), and the Senato, Deliberazioni, Terra (reg. 36 up to 80).

${ }^{44}$ ASV, Ufficiali alle Rason Vecchie, b. 379, [n. fol.] (3 July 1573).

45 ASV, Collegio, Cerimoniali, reg. 1, fol. 132v (28 July 1595); ASV, Senato, Deliberazioni, Terra, reg. 57 , fol. $18^{\mathrm{r}}$ (21 October 1586). 
Table 2: Overview of the amounts spent on refreshments for European ambassadors during the 1570 s

\begin{tabular}{|l|l|l|}
\hline \multicolumn{1}{|c|}{ Date } & \multicolumn{1}{|c|}{ Amount } \\
\hline 21 June 1572 & Mantua & $\begin{array}{l}\text { d. }[\text { ducati] } 26 £[\text { lire }] 1 \\
\text { s. }[\text { soldi } 6\end{array}$ \\
\hline 29 March 1573 & Navarre & d. $100 £ 2$ s. 3 \\
\hline 3 July 1573 & Rome & d. $31 £ 4$ s. 16 \\
\hline 2 December 1573 & Poland & d. $50 £ 5$ s. 4 \\
\hline 13 January 1574 & Savoy & d. $25 £ 2$ s. 6 \\
\hline 4 May 1574 & Florence & d. $25 £ 4$ s. 15 \\
\hline 22 June 1574 & Savoy & d. $27 £ 2$ s. 20 \\
\hline 1 June 1577 & Florence & d. $26 £-$ s. 6 \\
\hline 6 July 1577 & Grisons & d. $27 £ 5$ s. 2 \\
\hline 17 July 1577 & Urbino & d. $25 £ 3$ s. 11 \\
\hline 9 September 1577 & Savoy & d. $24 £ 6$ s. - \\
\hline 24 September 1577 & Parma & d. $28 £ 5$ s. 6 \\
\hline 27 September 1577 & Parma & d. $24 £ 2$ s. 13 \\
\hline 13 October 1577 & Mantua & d. $27 £ 4$ s. 2 \\
\hline 18 October 1577 & Mantua & d. $26 £ 4$ s. 4 \\
\hline 20 October 1577 & Ferrara & d. $23 £ 5$ s. 30 \\
\hline 21 October 1577 & Florence & d. $24 £ 3$ s. 12 \\
\hline 23 October 1577 & Ferrara & d. $28 £ 5$ s. 14 \\
\hline 25 October 1577 & Florence & d. $29 £ 4$ s. 1 \\
\hline 15 November 1577 & Sweden & d. $26 £ 5$ s. 6 \\
\hline 18 November 1577 & Sweden & d. $24 £ 5$ s. 14 \\
\hline
\end{tabular}

As already pointed out in the introduction, food was not the only element of diplomatic hospitality. An equally significant factor was the arrangement of appropriate lodgings. Both the ambassadors and the host states understood how the exterior of a house and the display of furnishings contributed to the construction of an image of power and wealth. Whereas ordinary ambassadors were responsible for making their own housing arrangements, the Venetian Republic 
offered free accommodation to extraordinary ambassadors in fully furnished residences; even when they came with an entourage of more than one hundred people, they were all lodged free of charge. While it has been the main ambition of this article to critically analyse food gifts, the source under study also enables an investigation of issues related to diplomatic housing, which again underlines the wealth of information we can extract from these lists of expenses. Therefore, to conclude, the article will briefly touch upon this topic in order to stress that the material culture of diplomacy is a fruitful subject for future research. ${ }^{46}$

When word about the stopover of the Muscovite delegation reached Venice, the officials of the Rason Vecchie prepared a residence in the Dominican monastery of San Giovanni e Paolo. The chambers were filled with lavish furniture rented from Jewish merchants in the ghetto: beds (letti) with bed sheets (ninzuoli, it. lenzuoli) and various bedcovers (coltre, it. coperte), of which two were of silk and one of suriana; ${ }^{47}$ several wall hangings of gilded leather (fornimento di cuori d'oro), textile (fornimento di spal[l]iere a saieta) and tapestries (fornimento di razi, it. arazzi); one antiporta a boscaia, a textile hung in the door opening, decorated with leaves and plants; numerous carpets, amongst which two carpets for the table (tapedi da tavola, it. tappeti da tavola) and two Egyptian carpets (caiarini); and silverware such as a basin (bacil, it. bacino), six damascened candlesticks (candelieri), and a refrescador, a large vase that carried water which was used to refresh the wine, and to adorn the credenza, or sideboard. The Venetian government made sure that the envoys were lodged in great style and surrounded by luxury. Nevertheless, despite Venetian efforts, the Muscovites were not impressed by their lodgings and they did not handle these furnishings

46 My doctoral dissertation carefully investigates every aspect of the material culture of French ambassadors stationed in Venice during the second half of the sixteenth century. It unites the various aspects of diplomatic material culture (furnishings, clothing, food, purchases, and gifts) and, this way, the complete material environment of early modern ambassadors is mapped, thereby revealing the interconnectedness of material culture and politics on every level of diplomatic life. See: Mesotten.

47 This fabric is probably from Syria, or imported from India through Syria by, most likely, Portuguese merchants. 
with the care and respect that they required. ${ }^{48}$ After their visit, damages had to be repaired and various stains had to be thoroughly cleaned. ${ }^{49}$

By hosting foreign dignitaries in a sumptuous environment, the Republic not only honoured the ambassador, but also applied material splendour as a strategy to showcase commercial prowess and technological expertise through the decoration of diplomatic lodgings with both exotic pieces and locally manufactured luxury goods. Every detail of hospitality was meticulously planned and manipulated, and it moulded the entire diplomatic scenery. Hospitality was undeniably an important element of diplomatic culture and constantly used as a political tool to gain favour with the government which the diplomat represented.

\section{CONCLUSION}

The aim of this critical analysis of a primary source was to shed light on a very specific document related to the field of diplomatic history, and to carefully examine what it tells us about diplomatic practices. Even though diplomatic correspondence remains of crucial importance for unravelling the internal machinations of early modern diplomacy, lists of expenses permit the exposure of the more tangible facets of diplomatic interaction, and they present us with a clear overview of the actual daily costs attached to the hosting of ambassadors. While the importance of hospitality has been analysed before, the exact nature of this generosity, and in particular the dynamics of food provision, deserved a closer examination. This article has revealed that food and diplomacy were firmly connected in early modern society. By emphasising the ceremonial surroundings of the Muscovite embassy in Venice, the symbolic and political messages that food conveyed have been brought into sharp focus. Food promoted the establishment of diplomatic ties and reflected and consolidated political hierarchies. Moreover, food provided a flavour of the nation's success and, this way, was a strong signifier of economic prosperity and diplomatic strength.

48 Possevino, p. 23.

49 ASV, Senato, Deliberazioni, Terra, filza (fz.) 85, [n. fol.] (25 September 1582). 


\section{BIBLIOGRAPHY}

\section{Archival Sources}

Venice, Archivio di Stato di Venezia

Collegio, Cerimoniali

reg. 1, 3

Collegio, Esposizioni Principi

reg. 5

Senato, Deliberazioni, Terra

reg. $36-80$

fz. 85

Ufficiali alle Rason Vecchie

b. 378,379

\section{Printed Primary Sources}

Pamjatniki Diplomatičeskich Snoshenii Drevnej Rossii s Derzhavami Inostrannymi, 10 vols (1851-1871), I (St. Peterburg: Izdatel'stvo: Tip. II Otdeleniya Sobstvennoy Ye.I.V. Kantselyarii, 1851)

Possevino, Antonio, The Moscovia of Antonio Possevino, S.J., ed. and trans. by Hugh F. Graham (Pittsburgh: University of Pittsburgh, 1977)

Sansovino, Francesco, Venetia Città Nobilissima et Singolare, con Aggiunta da D. Giustiniano Martinioni (Venice: Stefano Curti, 1663)

Sanudo, Marin, Diarii di Marino Sanuto, ed. by Rinaldo Fulin and others, 58 volumes (Venice: Visentini, 1879-1903), XVII (1886)

\section{Secondary Works}

Albala, Ken, Food in Early Modern Europe (Westport: Greenwood Press, 2003)

Bercusson, Sara, 'Gift-Giving, Consumption and the Female Court in SixteenthCentury Italy' (unpublished doctoral thesis, University of London, 2009)

Bernstorff, Marieke von and Susanne Kubersky-Piredda, eds, L'Arte del Dono: Scambi Artistici e Diplomazia tra Italia e Spagna, 1550-1650 (Milan: Silvana Editoriale, 2013)

Boerio, Giuseppe, Dizionario del Dialetto Veneziano, $3^{\text {rd }}$ edn (Venice: Reale Tipografia di Giovanni Cecchini Editore, 1867)

Brusegan, Marcello, 'Cisame de Pesse Quale Tu Voy': Il Pesce nelle Tavole Veneziane nei Secoli XIV-XVI (Venice: Centro Internazionale della Grafica di Venezia, 1992)

Carrio-Invernizzi, Diana, 'Gift and Diplomacy in Seventeenth-Century Spanish Italy', The Historical Journal, 51, no. 4 (2008), 881-99

Chatenet, Monique, 'The King's Space: The Etiquette of Interviews at the French Court in the Sixteenth Century', in The Politics of Space: European Courts, ca. 1500-1750, ed. by Marcello Fantoni, George Gorse and Malcolm Smuts (Rome: Bulzoni, 2009), pp. 193-208 
Cohen, Elizabeth S., 'Miscarriages of Apothecary Injustice: Un-Separate Spaces of Work and Family in Early Modern Rome', in Spaces, Objects and Identities in Early Modern Italian Medicine, ed. by Sandra Cavallo and David Gentilcore (Oxford: Blackwell Publishing, 2008), pp. 8-32

Cossalter, Stefanie, 'Dai Porti alle Isole: Cerimoniali di Accoglienza nella Serenissima', in Spazi Veneziani: Topografie Culturali di una Città, ed. by Sabine Meine (Rome, Venice: Viella, 2014), pp. 125-48

Dubrovskiy, I.V., 'Novyye Dokumenty po Istorii Otnosheniy Rossii i Italii pri Ivane Groznom', in Russkiy Sbornik: Issledovaniya po Istorii Rossii, ed. by M. Jovanovic and others, 14 vols (Moscow: Regnum, 2004-2013), XIV (2013), pp. 7-72

Dursteler, Eric R., 'Food and Politics', in A Cultural History of Food, ed. by Fabio Parasecoli and Peter Scholliers (London: Berg, 2012), III: A Cultural History of Food in the Renaissance, ed. by Ken Albala (2012), pp. 83-100

— , "A Continual Tavern in My House': Food and Diplomacy in Early Modern Constantinople', in Renaissance Studies in Honor of Joseph Connors, ed. by Machtelt Israëls and Louis A. Waldman (Cambridge: Harvard University Press, 2013), pp. 166-71

Ferraro, Joanne Marie, Venice: History of the Floating City (New York: Cambridge University Press, 2012)

Fletcher, Catherine, "“Those Who Give Are Not All Generous”: Tips and Bribes at the Sixteenth-Century Papal Court', EUI Working Papers MWP 2011/15, European University Institute, 2011, 1-10

Heal, Felicity, Hospitality in Early Modern England (Oxford: Clarendon Press, 1990) -, 'Food Gifts, the Household and the Politics of Exchange in Early Modern England', Past \& Present, 199.1 (2008), 41-70

Hosking, Geoffrey A., Russia and the Russians: A History (Cambridge: The Belknap Press of Harvard University Press, 2001)

Jansson, Maija, 'Measured Reciprocity: English Ambassadorial Gift Exchange in the Seventeenth and Eighteenth Centuries', Journal of Early Modern History, 9, no. 3 (2005), 348-70

Jeanneret, Michel, A Feast of Words: Banquets and Table Talk in the Renaissance, trans. by Jeremy Whiteley and Emma Hughes (Cambridge: Polity Press, 1991)

Komaroff, Linda, ed., Gifts of the Sultan: The Arts of Giving at the Islamic Courts (New Haven: Yale University Press, 2011)

Martin, Russell E., 'Gifts for the Bride: Dowries, Diplomacy, and Marriage Politics in Muscovy', The Journal of Medieval and Early Modern Studies, 38, no. 1 (2008), $119-46$

Matalas, Antonia-Leda, Eleni Tourlouki and Chrystalleni Lazarou, 'Fasting and Food Habits in the Eastern Orthodox Church', in Food and Faith in Christian Culture, ed. by Ken Albala and Trudy Eden (New York: Columbia University Press, 2011), pp. 189-204

Mesotten, Laura, 'Behind the Curtains of Diplomacy: The Household, Material Culture and Networks of French Ambassadors in Venice (1550-1610)' (unpublished doctoral thesis, European University Institute, 2017) 
Muir, Edward, Civic Ritual in Renaissance Venice (Princeton: Princeton University Press, 1981)

Mund, Stéphane, 'La Mission Diplomatique du Père Antonio Possevino (S.J.) chez Ivan le Terrible en 1581-1582 et les Premiers Écrits Jésuites sur la Russie Moscovite à la Fin du XVI e Siècle', Cahiers du Monde Russe, 45, no. 3-4 (2004), 407-40

Pedani, Maria Pia, In Nome del Gran Signore: Inviati Ottomani a Venezia dalla Caduta di Costantinopoli alla Guerra di Candia (Venice: Deputazione Editrice, 1994)

Shaw, James, and Evelyn Welch, Making and Marketing Medicine in Renaissance Florence (Amsterdam: Rodopi, 2011)

Urban, Lina, Banchetti Veneziani dal Rinascimento al 1797 (Belluno: Strategy \& People, 2007)

Laura Mesotten - received her PhD from European University Institute; e-mail: laura.mesotten@eui.eu 
APPENDIX

\section{Archivio di Stato di Venezia, Senato, Deliberazioni, Terra, Filza 85, 25 September 1582}

[fol. $\left.1^{\mathrm{r}}\right]^{50}$

1582 a dì 25 settembre

Spese fatte per l'officio delle Rason Vecchie de ordine del Illustrissimo Collegio nel spesar giornalmente il signor Ambasciator de Moscovia ${ }^{51}$ con Monsignor Posevino ${ }^{52}$ et altri al numero de trenta boche ordinarie da di 2 agosto giobia che arivorno fin ad 24 ditto che parti compreso il banchetto de quatro piati che si fece al arsenal, colacion $\mathrm{d} e$ Galea, e del campaniel et noli de robe con tutte altre spese come qui sotto distintamente sarà dechiarito e prima

A signor Niccolo forner di frati de San Zuanepollo ${ }^{53}$

Per pani numero mille cinquecento sesantanuove da $s .{ }^{54}$ do l'un diede in tuto il tempo compreso pani cento diede per l'arsenal monta $£$ cento cinquesie s. 18 cioè

d. $25 £ 1$ s. 18

Al ditto per quarte ${ }^{55}$ una farina burata per frizer pese, torte e paste diverse

d. $-£ 5$ s. -

E per pani 30 da s. 1 mezzo si comprò il primo zorno / et 40 per l'arsenal in tuto

d. $-£ 5$ s. 5

Per farina si comprò per l'arsenal

d. $-£ 2$ s. -

50 The entire filza has no folio numbering but is subdivided according to the dates of the documents. I have numbered the transcribed document in order to clearly structure the text.

51 Iakov Molvianinov.

52 Jesuit Antonio Possevino.

53 Basilica di San Giovanni e Paolo, known in Venetian as San Zanipolo or San Zuanepollo.

54 Three Venetian coins are listed in this source: ducati, lire and soldi. As these coins are constantly repeated throughout the text, they will be referred to in their standard abbreviated form, respectively: d., $£, s$.

55 Unit of measurement used for grain and wine in Venice; singular: quarta, plural: quarte. 
Signor Beneto Graseto al insegna della vida ${ }^{56}$

Per vin bianco quarte $5 \operatorname{secchi}^{57} 2$ a $£$ x / e negro quarte 4 a $£ 7$ s. 12 diede da di 2 auosto fin ad 6 ditto monta in tuto

d. $13 £ 4$ s. 16

\section{Signor Gasparo Volpin al insegna della Madonna}

Per vin bianco quarte 2 / a $£$ x / e negro quarte 2 / a $£ 8$ / diede a dì 7 ditto per l'arsenal

d. $5 £ 5$ s. -

Al ditto per vin bianco quarte 15 / e negro quarte $\mathrm{x}$ secchi 2 a ditto pretio per la casa

d. $37 £ 4$ s. 12

E per vin bianco quarte 2 / e negro quarte 2 / si comprò a [contadi] il dì della Madonna e de San Rocho a dito pretio lo portò Andrea gondolier e suo compagno con Isepo fachin

d. $5 £ 5$ s. -

\section{Signor Simone Lora}

Per sechi quatro romania dolce bianca a $£ 3$ mezzo il secchio

d. $2 £ 1$ s. 12

Signor Remedio

Per malvasia secchi quatro / e liatico secchi do diede per l'arsenal a $£ 4$ il secchio

d. $3 £ 5$ s. 8

Al ditto per malvasia secchi vintiquatro diede per la casa

d. $15 £ 3$ s. -

Al ditto per asedo per l'arsenal e per la casa

d. $2 £ 2$ s. 16

Olio per l'arsenal quarti tre a ragion de $£ 14$ s. 16 il miro ${ }^{58}$

d. $1 £ 4$ s. 18

Ditto per la casa miri sei e $1 / 4$ a ditto pretio monta

d. $14 £$ [illegible] s. 14

56 Every Venetian shop was marked with a distinctive sign.

57 Unit of measurement used for wine in Venice; singular: secchio, plural: secchi.

58 Unit of measurement used for oil in Venice; singular miro, plural miri. 
Signor Zuane de Battista [Alto]bello e compagni

Per varuoli, porcelle, corbi, brancini, cievali, orae vecchie, barboni, sfogi et altri pessi diversi diede per la casa dacordo con i Clarissimi Signori

d. $100 £-$ s. -

Ali detti per pessi simili diede per il banchetto del arsenal dacordo con detti Signori in

d. $27 £-$ s. -

E per pessi diversi comprad $i$ per pescaria $£$ nonanta s. $16 /$ cioè

d. $14 £ 4 \mathrm{~s} .-$

Per botarghe, caviaro, baise de morena, tarantelo e inchio per l'arsenal

d. $2 £ 5$ s. 16

Per salumi simili per la casa in tutto il tempo

d. $3 £ 5$ s. 8

Candelle de seo in tuto il tempo per la montar de

d. $8 £ 4$ s. 12

d. $281 £ 2$ s. 7

[fol. $\left.1^{\mathrm{v}}\right]$

\section{Simone polaruol}

Per caponi, gali d'india, anere, pola $n$ che, colombini e polastri per

d. $24 £ 4$ s. 14

Vedello da rostir e lesar

d. $7 £ 3$ s. 12

Manzo

d. $3 £ 1$ s. 5

Nomboli quatro

d. $-£ 4$ s. 4

Formazo piacentin, lardo e salad $£$ diese s. - / e per contad $i$ al casaruol dal San Marco per lengue, marzolini, mortadelle et altro $£ 7$ s. 18 sono in tuto

d. $2 £ 5$ s. 10

Per candele de cera il primo giorno $£ 2 \mathrm{~s} .12$ / et spizarie a d $\imath 2 \mathrm{e}$ a di $5 £ 5$ s. 4 in tuto 


\section{Later dalla Madalena}

Per cai d $e$ late, zonchiad $a$ e late grassa

d. $2 £-$ s. 12

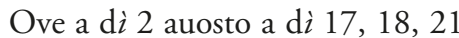

d. $1 £ 1$ s. 10

Onto sotil a di 2 et a di 18

d. $1 £-$ s. 13

Risi, susini, tamaro, narance, cedri, sal negro e bianco

d. $-£ 4$ s. 8

Per l'arsenal narance, cedri, uvapasa, curadenti, fiori

d. $-£ 3$ s. 6

Per l'arsenal zuchero pani do per averli desmentegà a tuor con le altre spese

d. $-£ 5$ s. 4

Agua de vitta in più volte

d. $-£ 4$ s. 12

Meloni e angurie per l'arsenal

d. $1 £ 2$ s. -

Meloni e angurie per la casa

d. $6 £ 5$ s. -

Uva de tre sorte, fighe, perseghe, [illegible] et altre frute per l'arsenal

d. $3 £ 2$ s. -

Frute simile per la casa in tuto il tempo

d. $9 £ 4$ s. 4

Erbazi de ogni sorte in tutto il tempo

d. $1 £ 5$ s. 6

Signor Marco Anttonio spezier ai do pomi de oro

Per confetioni e spitiarie diverse diede per il disnar del arsenal

d. $5 £ 3$ s. 11

E per robe simile diede per la casa per la montar de

d. $15 £ 5$ s. 5

Signor Verzilio spezier al insegna spada

Per confetioni diverse diede per l'arsenal per la montar de $£ 46$
s. 15
d. $7 £ 3$ s. 7
E per robe simile per la casa $£ 31$ s. 18
d. $5 £-$ s. 18 
Signor Lorenzo Salla spezier al San Michiel

Per candele da tavola e un torzo per la casa $£ 34$ s. 17

d. $5 £ 3$ s. 17

Signor Matio spezier de medicina al vaso a San Zuanepolo

Per cassia, siropi, ague stilade et altro per i amalad $i$ e feriolo

d. $3 £ 1$ s. -

Per contadi al Eccellente messer Apolonio Massa visito i sopradetti scudo un

d. $1 £-$ s. 16

Al barbier cavo sangue al secretario del ambasciator

d. $-£ 1$ s. 10

Per una schragna de legno e de piera dentrovia per li detti

d. $-£ 1$ s. 10

Signor Piero Verier drio calonega per veri diversi diede in tuto il tempo

d. $3 £ 3$ s. 5

Per un casso da fachin per andar sue zoso con robe per la casa

d. $-£ 1$ s. -

Spese minude fatte per il Clarissimo Loredan d. 3 s. 5 / e per Felipo suo zovane
d. $1 £ 4$ s. 9
d. $4 £ 4$ s. 14
d. $123 £ 3$ s. 9

[fol. $\left.2^{\text {r }}\right]$

Mercede e nolli diversi

Per contadi a quatordiese musici de canto e suono per la musica del arsenal d. $22 £ 1$ s. 11

A facio scalco servi al arsenal per mercede e nollo de robbe

d. $5 £ 2$ s. Anttonio cuogo servi ut supra per sue mercede e nollo de robbe d. $1 £ 4$ s. -

Contadi a Pasquale fante spese in le barche dalle Zafusine ${ }^{59}$ portò le robe del ambasciator et disnar a 12 gondolieri andò a levar / e per tuoy robbe in gheto / e per il suo ritorno da

59 In early modern times, Lizza Fusina was an important harbour at the edge of the Venetian lagoon. 
Padova con do altri omeni et altre spese minude in tuto $£ 42$ s. -

Al gondolier portò la polizza de Pasqualin dalle Zafusine

d. $-£-$ s. 12

3 auosto contad $i$ Andrea gondolier per dodiese omeni andò con le barche alla Zafusine a levar l'ambasciator $£ 36$ / et li altri 4 omeni vogò con due barche al servitio di detto ambasciator e si pagerà in ultima

5 ditto a quatro omeni vogò con le gondole i signori savii $\mathrm{d} e$ ordini

7 ditto in barcha per mandar robe sue zoso in arsenal e per vogar quei del ambasciator

8 ditto a tre gondole vogò il secretario, l'ambasciator et altri per aver lasa le gondole in rio de palazzo et signori venuti a pied $i$ a Rialto ove se inbarcò

d. $-£ 1$ s. 10

11 ditto a Marco gondolier alle colone / et un altra gondola vogò il secretario Franceschi, ${ }^{60}$ l'ambasciator et altri

d. $-£ 1$ s. 16

13 ditto contadi al secretario Franceschi disse aver speso in barcha

d. $-£ 2$ s. 8

24 ditto contadi Andrea gondolier per dar a tre gondole oltra le due de casa per vogar l'ambasciator alle Zafusine a s [illegible] per una a doi remi

d. $9 £ 1$ s. 6

24 ditto contadi al ditto per dar alle doi barche da Padova che si mandò a traghetar alle Zafusine cioè Bortolo Ogniben e suo compagno a $£ 15$ per barcha

d. $4 £ 5$ s. 4

25 ditto contadi Andrea sopraditto Zerbin / et altri doi compagni servi con due gondole l'ambasciator zorni vintitre a s. 40 per un al zorno

d. $29 £ 4$ s. 4

${ }^{60}$ Marcantonio Franceschi, secretary of the Venetian Senate. 
25 ditto in gondola im più volte spese il sopraditto in tuto il tempo

d. $1 £ 2$ s. -

25 ditto contad $i$ a Valentin piater portò le robe in drio in gheto

d. $-£ 1$ s. -

25 ditto Anttonio cuogo e galiner per doi caponere

d. $-£ 5$ s. -

25 ditto contad $i$ a Pasqualin fante servi alla despensa zorni 23

d. $7 £-$ s. -

25 ditto contadi Anttonio Salvagno servi ut supra

d. $7 £-$ s. -

25 ditto a Isepo fachin servi in tute le facion della casa

d. $7 £-$ s. -

Al Reverendo padre prior de San Zuanepolo per legne e sal diede per i detti

d. $11 £-s .-$

Contad $i$ alli cuoghi e sotto cuoghi ha cusinado 23 zorni

d. $10 £-$ s. -

E per contadi al Reverendo fra Isepo prestò la sua camera per dano $\mathrm{d} e$ robe rote e perse e per nollo de biancharie e spese per lui fatte in far lavar li drapi a l'ambasciator d. vinti

d. $20 £-$ s. -

Al ditto per dar al converso servi li amaladi et al portoner et al giovine de camera $\mathrm{d}$. doi fra tuti tre

d. $2 £-$ s. -

d. $146 £ 3$ s. 1

[fol. $\left.2^{\mathrm{v}}\right]$

Seguita nolli diversi

A signor Gierolamo scalco

Per nollo de letti cinque forniti, un bacil e sie candelieri alla damaschina $e t$ un refrescador $e t$ altre robbe per zorni 25

d. $9 £-$ s. -

Orso dalla Man ebreo

Nollo de un fornimento de razi de peci cinque / doi taped $i$ da tavola de braccia 6 l'uno / doi caiarini de braccia 2 mezzo / doi coltre de seda, un antiporta a boscaia tenute zorni 30 per la venuta 
$\mathrm{d} e \mathrm{l} \mathrm{D} u$ ca de Mantua che alogio lì e per dano de una coltra machia in tutto

d. $10 £-$

\section{David Luzato}

Nollo de un fornimento de cuori de oro nuovi alti braccia cinque fu braccia trenta tenuti giorni 30

d. $8 £-$

\section{Marchuzo ebreo}

Nollo de letti doi fornidi del tuto et pera un de ninzuoli lavradi per l'ambasciador per zorni 30

d. $2 £-$

\section{Caliman et Calimani}

Nollo de peci quatro raci / taped $i$ [braccia 5] / et cuori braccia 41 alti quarte $\mathrm{x} /$ et pezo undiese braccia 4 mezzo alto braccia 5 per zorni 30

d. $4 £-$

\section{Marcho della Baldosa}

Nollo de robbe et coltra una suriana depenta ritenuta dai frati per una altra sua che disse esserle sta porta via dai schiavi

d. $3 £-$

\section{Moise de Ventura et Grasini}

Nollo de un fornimento de spaliere a saieta usade per zorni 30

d. $2 £-$

d. $38 £-$ $281 £ 2$ s. 7

$123 £ 3$ s. 9

Andrea Donado procurator alle Rason Vecchie $146 £ 3$ s. 1

Summa summarum d. $589 £ 2$ s. 13

Officio Rason Vecchie secretarius 
[fol. $3^{\text {r }}$

Il numero de quelli che furono spesati e prima

Il signor Giacomo poslanich ${ }^{61}$ ambasciator Moscovito ${ }^{62}$ Techin $^{63}$ suo secretario over scrivan

Giacomo Zaborosch ${ }^{64}$ tolmachio over interpetre Servitori delli doi moscoviti quatro

Il padre Anttonio Posevino jesuito

Dui suoi nepoti preti jesuiti

Un secular suo scritor

Un giovine polacho

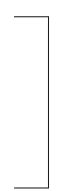

numero 7

Giovanni Battista palavesini milanese

Schiavi spagnoli e marchiani cinque

Gondolieri quatro

Despensieri doi

Fachin uno

Cuoghi e sotto cuoghi quatro

\section{Stra ordinarii}

Fratti che servira alla camera et ai amalad $i$ et altri

Il scocese et altre giente menate dal Posevino

${ }^{61}$ Poslannik, the Russian word for envoy.

${ }_{62}$ Iakov Molvianinov.

${ }^{63}$ Vasily Tishina.

${ }^{64}$ Jakub Zaborowski, not a Russian, but a Pole. 